\title{
Preparation and characterization of attapulgite microcapsules coated with acrylic polymer
}

\author{
Lining Song (ORCID ID: 0000-0002-5671-4745), Zhenxu Li ${ }^{1)}$, Lina Yang') (0000-0002-5518-050X),

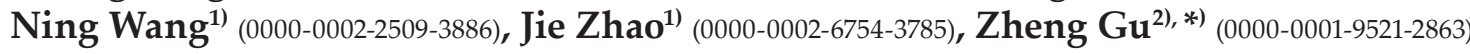 \\ DOI: dx.doi.org/10.14314/polimery.2021.2.4
}

\begin{abstract}
The attapulgite core-shell microcapsule type flame retardant was prepared by in situ polymerization. Attapulgite (ATP) was used as a core material with poly(methyl methacrylate) (PMMA) and poly(methyl methacrylate-co-acrylic acid) [P(MMA-co-AA)] as shell materials. The attapulgite was modified by the silane coupling agent. The effects of different shell materials and modification methods on the structure and properties of attapulgite core-shell microcapsules were studied by scanning electron microscopy, particle size distribution, infrared analysis and thermogravimetric analysis. The results showed that the coating effect was best when the amount of silane coupling agent was $1 \%$ of the attapulgite mass. The particle size of the microcapsule prepared with PMMA as shell material was uniform and the coating efficiency was better. After the copolymerization of acrylic acid (AA) in MMA shell materials, the cladding efficiency was improved. At the same time, the thermal decomposition temperature of the microcapsule shell material was greatly reduced, which is beneficial to the performance of attapulgite flame retardant.
\end{abstract}

Keywords: microcapsule, attapulgite, methyl methacrylate, acrylic acid, silane coupling agent.

\section{Otrzymywanie i charakterystyka mikrokapsułek attapulgitu powlekanych polimerami akrylowymi}

\begin{abstract}
Streszczenie: Metodą polimeryzacji in situ otrzymano uniepalniające attapulgitowe mikrokapsułki o budowie typu rdzeń-otoczka. Rdzeń stanowił attapulgit (ATP) modyfikowany silanowym środkiem sprzęgającym, a poli(metakrylan metylu) (PMMA) lub poli(metakrylan metylu-co-kwas akrylowy) [P(MMA-co-AA)] - otoczkę. Wpływ rodzaju użytego materiału powłokowego i metody modyfikacji na strukturę i właściwości otrzymanych mikrokapsułek oceniano metodą skaningowej mikroskopii elektronowej, na podstawie rozkładu wielkości cząstek, analizy widm w podczerwieni i analizy termograwimetrycznej. Najlepsze właściwości wykazywała otoczka attapulgitowego rdzenia otrzymana z zastosowaniem środka sprzęgającego w ilości 1\% mas. ATP. Wielkość mikrokapsułek wytworzonych z udziałem PMMA była jednorodna, a efektywność powlekania ATP modyfikowanego silanowym środkiem sprzęgającym była większa. Wydajność powlekania za pomocą kopolimeru P(MMA-co-AA) była lepsza niż w wypadku PMMA, a znacznie niższa temperatura rozkładu termicznego kopolimeru stanowiącego otoczkę mikrokapsułki stwarza korzystne warunki dla uniepalniającego działania attapulgitu.
\end{abstract}

Słowa kluczowe: mikrokapsułka, attapulgit, metakrylan metylu, kwas akrylowy, silanowy środek sprzęgający.

ATP is the abbreviation for attapulgite, also known as palygorskite, which is a special rod-like magnesiumaluminum silicate mineral [1]. Because attapulgite has rich internal pores, it contains a lot of crystal water, and is rich in elements such as magnesium and aluminum.

\footnotetext{
1) Qingdao University, School of Chemistry and Chemical Engineering, 308 Ningxia Road, Qingdao, Shandong P.R.C. 266071.

2) Qingdao University, School of Materials Science and Engineering, 308 Ningxia Road, Qingdao, Shandong P.R.C. 266071.

*) Author for correspondence: guzheng596@163.com
}

Therefore, high temperatures can produce oxides such as $\mathrm{MgO}$ and $\mathrm{Al}_{2} \mathrm{O}_{3}$ covering the surface of the polymer matrix as an isolation layer. It has a flame retardant effect $[2,3]$. However, attapulgite also contains impurities that have poor compatibility with various polymers/composites thus reducing its flame retardant effect. In recent years, in order to solve this phenomenon, researchers have used different methods to purify, modify, and coat the attapulgite, thereby enhancing the dispersion and compatibility of the attapulgite and the polymer matrix $[4,5]$.

Studies have found that the various properties of modified attapulgite can be fully utilized, and the modifica- 
tion methods have become increasingly mature, which is an important direction for researchers to explore [6]. Wang et al. [7] mixed $8 \mathrm{wt} \%$ ATP, acid-treated ATP and silane coupling agent $\mathrm{KH}-560$-treated ATP into castor oil to prepare polyurethane/attapulgite (PUR/ATP) nanocomposites, and systematically studied the influence of the three modified attapulgite pairs on the various properties of PUR/ATP nanocomposites. The results showed that $8 \mathrm{wt} \%$ of the three ATPs can significantly enhance the castor oil-based PUR, and the silane coupling agent modification treatment has a more effective enhancement effect than the acid treatment. Ling et al. [8] modified ATP, activated by hydrochloric acid, with the silane coupling agent $\mathrm{KH}-570$ to improve the adsorption performance of ATP to dyes. The experimental results showed that the modified attapulgite had a strong adsorption capacity for methylene blue. The adsorption of methylene blue on KH570-ATP increased the decolorization rate to $79.55 \%$. Poly(methyl methacrylate) (PMMA) has a stable structure, environmental protection, high thermal stability, and good compatibility with various polymers [9-12]. The modification of attapulgite can be significantly improved. Wang Pinghua et al. [13] used in situ polymerization to graft MMA monomer on the surface of modified attapulgite, and then compounded with LDPE (low density polyethylene) to prepare LDPE/ATP nanocomposites. The results showed that attapulgite and PMMA coated on the surface can effectively solve the interface bonding problem of the composite material, and effectively reduced the polymerization inhibition effect of MMA, and improved the comprehensive performance of the composite material.

This topic first uses PMMA as the surface coating material of attapulgite, coated with attapulgite modified by silane coupling agent $\mathrm{KH}-570$, and regulates the modification method and temperature of attapulgite. Then, acrylic acid (AA) was used as the second comonomer to copolymerize with the polymerized monomer methyl methacrylate (MMA) to enhance the coating effect of attapulgite, improve the compatibility and dispersity of attapulgite in various polymers, and to analyze and study its various properties.

\section{EXPERIMENTAL PART}

\section{Materials}

Attapulgite (ATP, industrial grade, Gongyi Yuanheng Water Purification Material Factory), hydrochloric acid (chemically pure, Sinopharm Chemical Reagent Co., Ltd.), methyl methacrylate (MMA, chemically pure, Sinopharm Chemical Reagent Co., Ltd.), acrylic acid (AA, chemically pure, Sinopharm Chemical Reagent Co., Ltd.), $\gamma$-methacryloxypropyltrimethoxysilane $(\mathrm{KH}-570$, chemically pure, Nanjing Youpu Chemical Co., Ltd.), absolute ethanol (analysis pure, Sinopharm Chemical Reagent Co., Ltd.), self-made deionized water, glacial acetic acid (chem- ical pure, Sinopharm Chemical Reagent Co., Ltd.), ammonium persulfate (analytical pure, Sinopharm Chemical Reagent Co., Ltd.).

\section{Preparation of attapulgite microcapsules}

Surface treatment of attapulgite: an appropriate amount of attapulgite was placed in a beaker. Separately, the silane coupling agent $\mathrm{KH}-570$ (1\% mass of the mass of attapulgite) was diluted to $10 \%$ with absolute ethanol. The coupling agent in ethanol was added to the attapulgite uniformly and continuously stirred (JRJ300-SH digital display shearing emulsifying mixer, Shanghai Specimen Model Factory). The mixed product was placed in an oven (101-3A electric heating blast drying oven, Tianjin Test Instrument Co., Ltd.) at $45^{\circ} \mathrm{C}$ to dry for 2 hours, and then ground to obtain alkylated attapulgite.

\section{Preparation of PMMA-coated attapulgite core-shell microcapsules}

A certain amount of modified attapulgite in deionized water was dispersed, sheared and stirred at $3000 \mathrm{rpm}$ for 10 minutes, and the turbid liquid was transferred, after dispersion was complete, into a three-necked flask with a stirrer. The temperature was raised to $60^{\circ} \mathrm{C}$, then add $0.23 \mathrm{~g}$ of initiator ammonium persulfate to initiate polymerization for 2.5 hours. After completion of the reaction, the obtained product was suction filtered with a circulating water vacuum pump [SHZ-D (III) circulating water vacuum pump, Zhengzhou Keda Machinery Equipment Co., Ltd.], washed twice with absolute ethanol and deionized water respectively, ground and then dried in an oven to obtain PMMA coated attapulgite core-shell microcapsules.

\section{Preparation of acidified attapulgite microcapsules}

Anhydrous ethanol was added to attapulgite and diluted to $10 \%$ concentration, sheared and stirred at $55^{\circ} \mathrm{C}$, $800 \mathrm{rpm}$ for 60 minutes, then washed 5 times with deionized water, dried, and ground.

The acidified attapulgite was added to ethanol and dispersed ultrasonically for 10 minutes to make the attapulgite become a flocculent turbid liquid. Meanwhile, the silane coupling agent was hydrolyzed - the molar ratio of silane coupling agent to water was $1: 3$. The $\mathrm{pH}$ was adjusted to 2.5-3 with glacial acetic acid, hydrolyzed at $60^{\circ} \mathrm{C}$ and stirred at $800 \mathrm{rpm} 1$ hour. Finally, the silane coupling agent hydrolysate was taken and dispersed in ethanol at a ratio $2 \%$ of the mass of attapulgite. After $10 \mathrm{~min}-$ utes of ultrasonic dispersion, the mixture was heated at $70^{\circ} \mathrm{C}$ in a three-necked flask, stirred rapidly, reacted for 120 minutes and the product was filtered, washed, vacuum dried at $45^{\circ} \mathrm{C}$, crushed, and sieved to obtain the acidified attapulgite [14].

Preparation of PMMA coated acidified attapulgite core-shell microcapsules: the method is the same as in 
a)

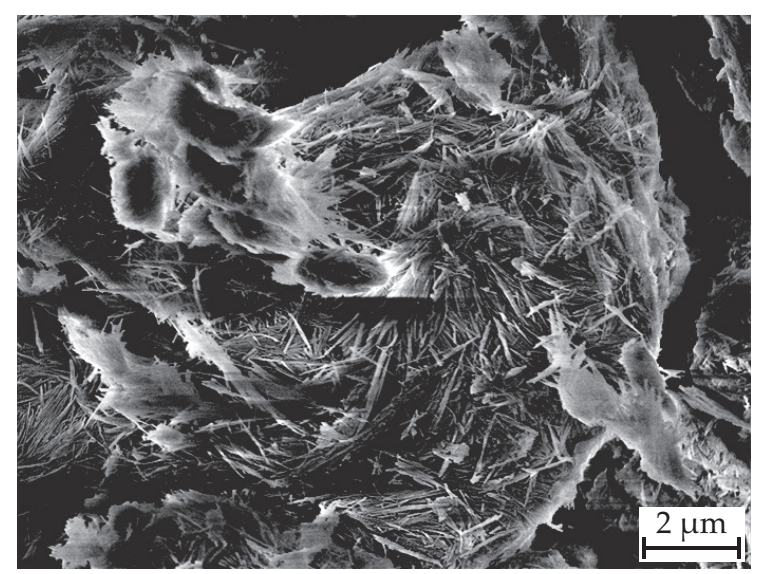

c)

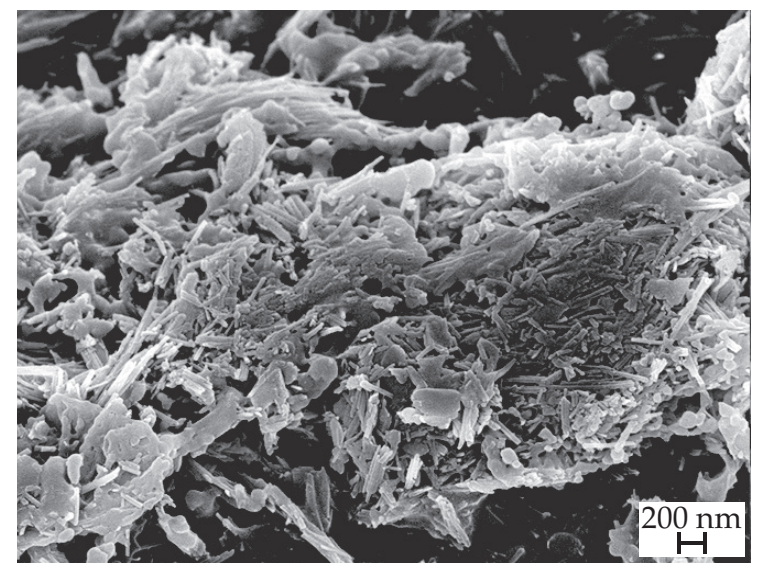

e)

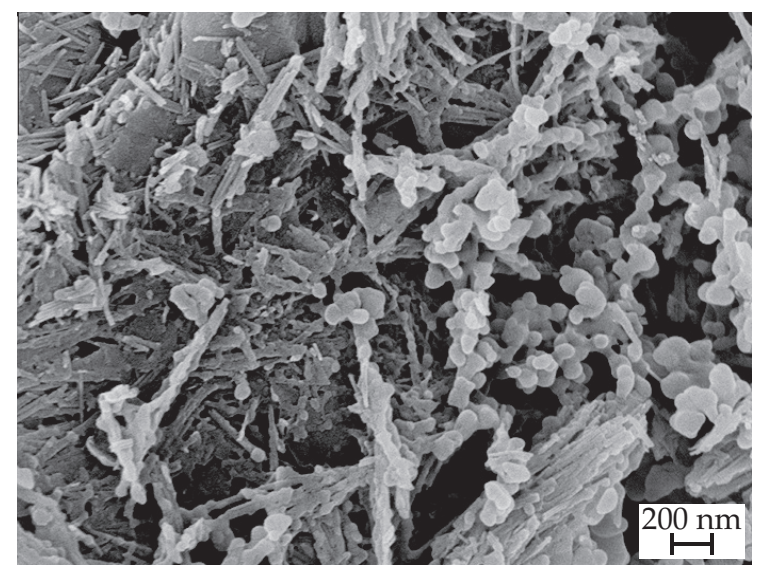

g)

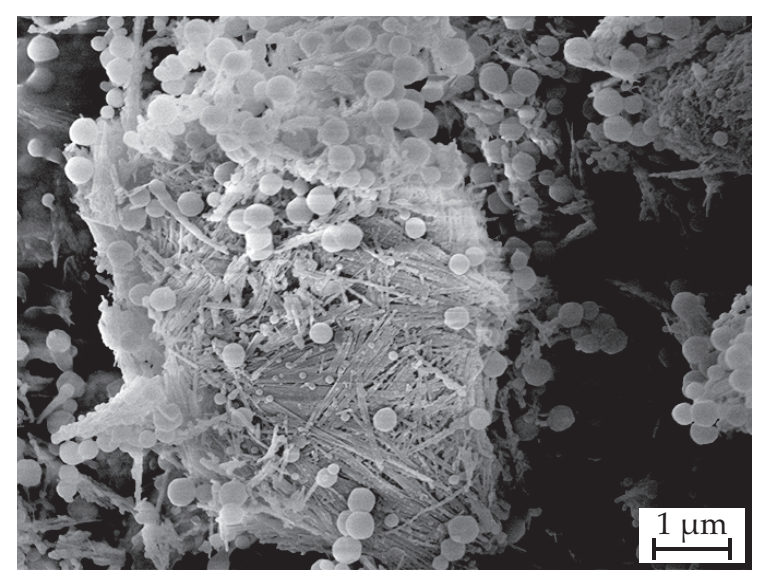

b)

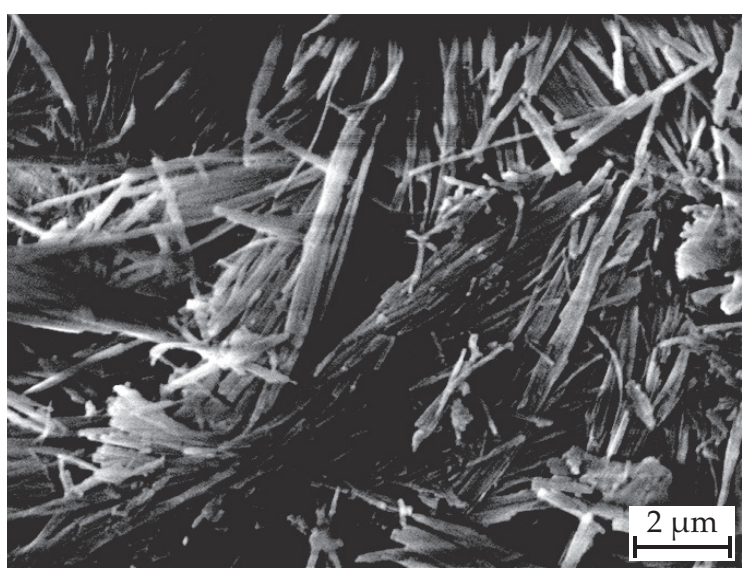

d)

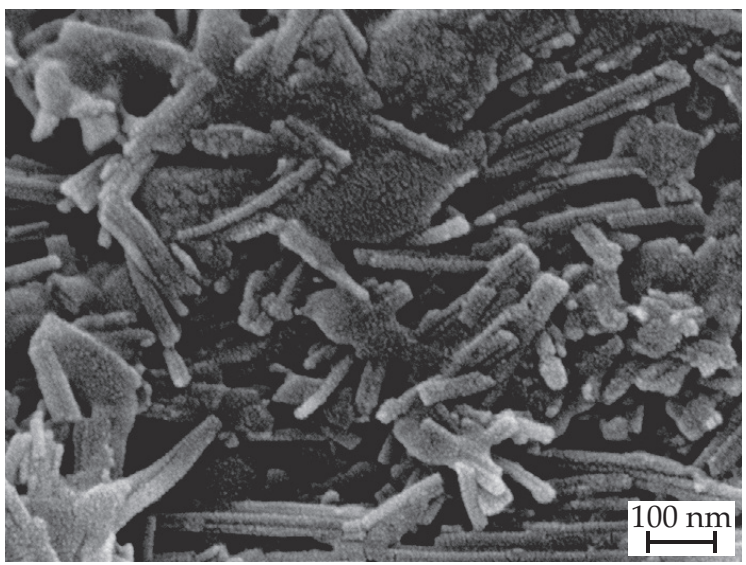

f)

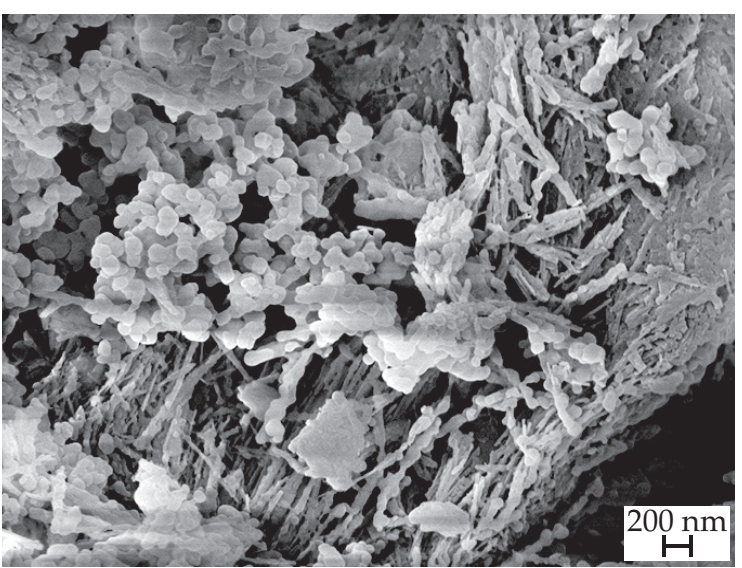

h)

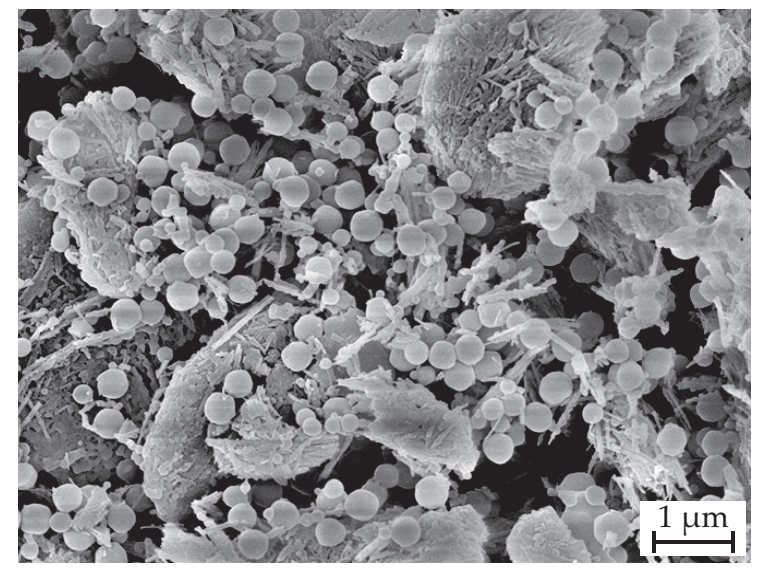

Fig. 1. Scanning electron microscopy: a), b) - uncoated ATP, c), d) $-60^{\circ} \mathrm{C}, 1 \mathrm{wt} \% \mathrm{KH}-570$ treatment, e), f) $-60^{\circ} \mathrm{C}, \mathrm{HCl}, 1 \mathrm{wt} \% \mathrm{KH}-570$ treatment, g), h) $-70^{\circ} \mathrm{C}, \mathrm{HCl}, 1 \mathrm{wt} \% \mathrm{KH}-570$ treatment 
the case of PMMA coated attapulgite core-shell microcapsules.

\section{Methods of testing}

\section{Scanning electron microscope (SEM)}

The finished product of attapulgite microcapsules was vacuum sputtered with gold on the surface, and the surface morphology of the particles was carefully observed with a high-resolution field emission scanning electron microscope (Zeiss SIGMA 500/VP, German Carl Zeiss company).

\section{Infrared absorption spectroscopy (FT-IR)}

The sample was ground and scanned with an iS50 Fourier transform infrared spectrometer (U.S. Thermo Fisher company), with a resolution of $1 \mathrm{~cm}^{-1}$ and a scan frequency of 32 times.

\section{Thermogravimetric analysis (TGA)}

The integrated thermal analyzer (HCT-1 Comprehensive Thermal Analyzer, Beijing Hengjiu Scientific Instrument Factory) was used to observe the decrease in sample mass with increasing temperature. The thermogravimetric analysis of the sample started at room temperature and ended at $650^{\circ} \mathrm{C}$, with a heating rate of $10^{\circ} \mathrm{C} / \mathrm{min}$.

\section{Particle size distribution test (PSD)}

An appropriate amount of finished powder was taken into the sampling tube, an appropriate amount of deionized water was added for dispersion, placed into an ultrasonic instrument for ultrasonic dispersion, and then dropped into the sampler (BT-50 Ultrasonic Disperser, Dandong Better Instruments Co., Ltd.) for particle size testing.

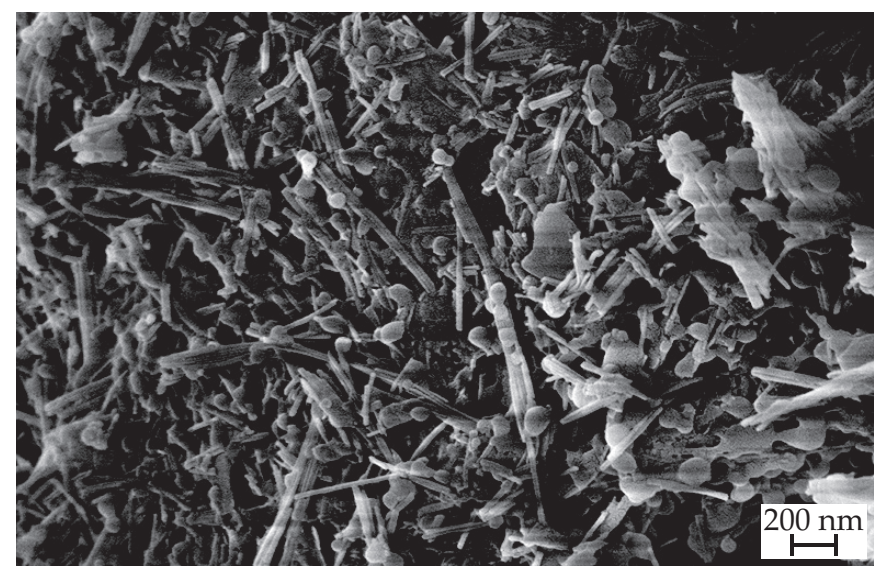

\section{RESULTS AND DISCUSSION}

\section{Surface topography analysis}

The SEM images of pure attapulgite samples and modified attapulgite particles are shown in Fig. 1.

According to Figs. 1a, 1b , the uncoated attapulgite particles mainly present irregular rod-like structures with diameters between $0.5-5 \mu \mathrm{m}$ and different lengths. After modification and surface coating with methyl methacrylate, the surface morphology of attapulgite changed significantly (Figs. 1c-h). As shown in Figs. 1c, 1d, when the amount of silane coupling agent $\mathrm{KH}-570$ is $1 \%$ of the mass of attapulgite, a thicker PMMA shell is formed on the surface of the attapulgite, and the coating efficiency was about $80 \%$. When the attapulgite was acidified with hydrochloric acid, as shown in Figs. 1e, 1f, the effect of the grafted KH-570 small molecules on the polymerized MMA monomer was reduced, and the density of the polymers was different. The surface MMA had fewer polymerization sites, and the self-aggregation of MMA into spheres was more obvious, and the coating rate was about $50 \%$; when the reaction temperature was raised to $70^{\circ} \mathrm{C}$, as shown in Figs. $1 \mathrm{~g}, 1 \mathrm{~h}$, the crystal boundary of attapulgite treated with hydrochloric acid is clear and the overall structure of attapulgite was well maintained but the increased temperature did not reduce the selfaggregation of MMA.

The electron micrograph of the modified attapulgite particles prepared by adding acrylic acid as the second polymer is shown in Fig. 2.

The experiment maintained the core-to-shell ratio as $1: 1$, the additional amount of the two polymeric shell materials was $m_{\mathrm{MMA}}: m_{\mathrm{AA}}=10: 1$, and the dosage of $\mathrm{KH}-570$ was $1 \%$ of the mass of attapulgite. Through the comparison with Fig. 1a, it can be clearly observed that the coating effect of $\mathrm{P}(\mathrm{MMA}-\mathrm{co}-\mathrm{AA})$ on attapulgite was greatly improved, but the dispersibility decreased (Fig. 2). The reason for this phenomenon is that in the

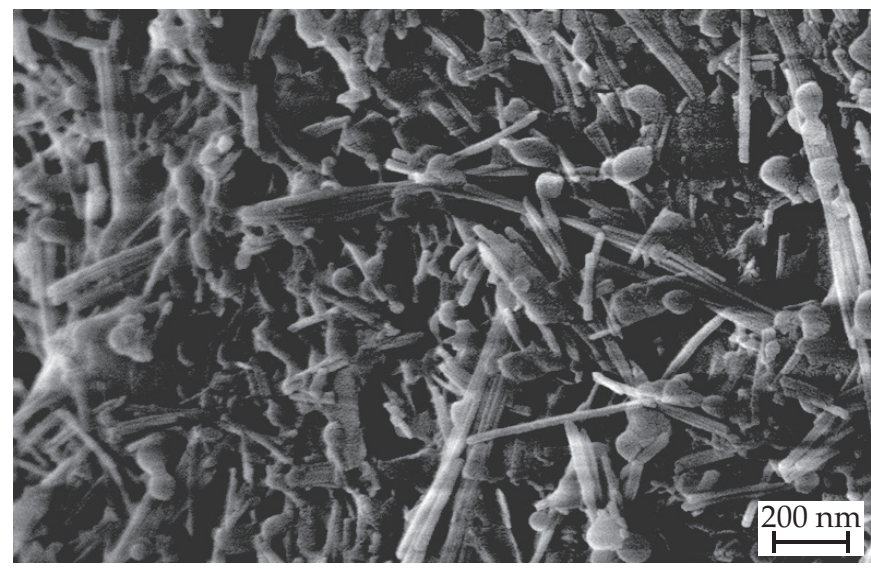

Fig. 2. Scanning electron microscope image of P(MMA-co-AA) copolymer shell material 


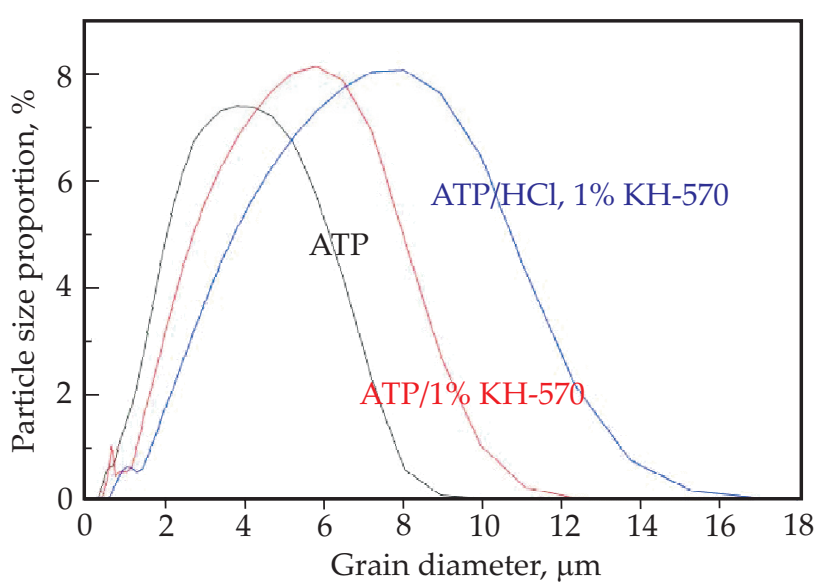

Fig. 3. Granularity test results of: uncoated ATP; 1 wt \% KH-570 processing; $\mathrm{HCl}, 1 \mathrm{wt} \% \mathrm{KH}-570$ processing

process of the reaction, the surface energy and dispersion interaction were controlled by grafted $\mathrm{KH}-570$ organic groups to change the hydrophobicity and balance the characteristics of the attapulgite, and improve the compatibility of the attapulgite and the matrix, but the unit attachment amount of $\mathrm{KH}-570$ small molecules on the surface of attapulgite was not the same. Therefore, during the polymerization process, the amount of PMMA deposited on the surface of attapulgite varied greatly. As the reaction continued, more and more MMA monomers participated in the polymerization, the PMMA deposited on the surface of the attapulgite increased, and the coverage area gradually increased until entire attapulgite particles were covered. Then, the comonomer AA was added, and the intermolecular homopolymerization of MMA occured. At the same time, it also undergoes copolymerization with AA. The location and time of precipitation are random and ultrasonic dispersion cannot be carried out during the entire experiment so that although the coating rate is greatly increased, adhesion occurs.

\section{Particle size analysis}

The particle size test results of pure attapulgite samples and attapulgite microcapsules are shown in Fig. 3.

From the particle size distribution, most untreated attapulgite samples are distributed between 0.29-7.45 $\mu \mathrm{m}$, with a medium particle size, D50 of $3.368 \mu \mathrm{m}$. Compared with the original attapulgite sample, the particle size of core-shell particles prepared by 1 wt \% KH-570 modified attapulgite clay had a slight increase, and the median particle size reached $4.556 \mu \mathrm{m}$, which shows the success of preparation of attapulgite core-shell particles; after acidizing the attapulgite, it can be observed that the D10, D50, and D90 of the sample decreased slightly. The reason for this phenomenon is the number of silane coupling agent $\mathrm{KH}-570$ molecules grafted on the surface of attapulgite decreased after acidification, which affected the particle size test results. The particle size of the attapulgite microcapsules prepared by adding AA as the

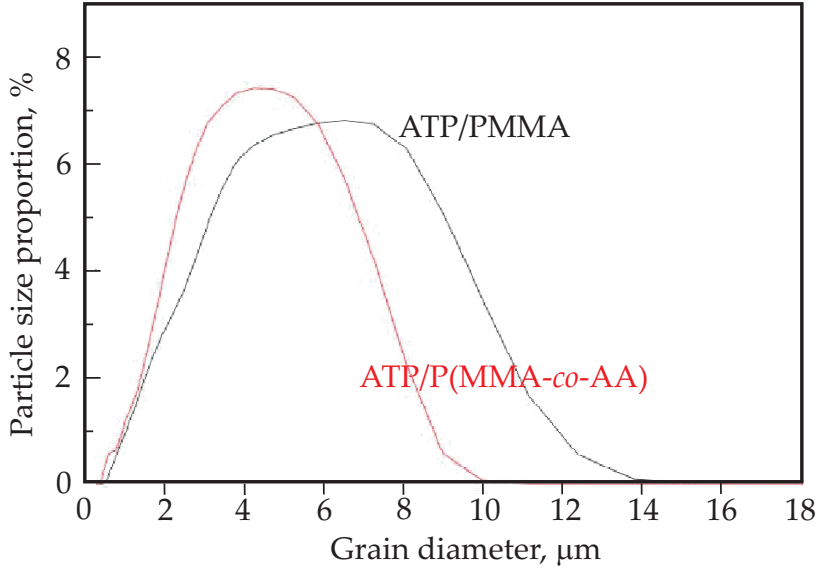

Fig. 4. Granularity test results of PMMA/ATP, P(MMA-co-AA)/ATP

second comonomer is significantly larger than that of the original attapulgite. As shown in Fig. 4, the median diameter of the attapulgite microcapsules reached $4.279 \mu \mathrm{m}$. Compared with the original attapulgite particles, the average particle size was $0.911 \mu \mathrm{m}$ larger, but the average particle size of the MMA alone coating is $0.277 \mu \mathrm{m}$ larger than that of the P(MMA-co-AA) copolymer. Combined with the electron microscopy observations, it can be seen that when the coating rate is similar, the P(MMA-co-AA) copolymer can be better uniformly dispersed on the attapulgite particles.

\section{Thermal performance analysis}

Due to the special mineral structure of attapulgite, its mass loss is mainly caused by the loss of adsorbed water on the surface, cation-bound structured water in the middle of the octahedral layer, adsorbed water in the pores inside the crystal, and loss of crystal water. Figure 5 shows the TGA thermal mass loss curve of untreated attapulgite. The temperature rise range starts from room temperature to $650^{\circ} \mathrm{C}$ and the temperature rise rate is $10^{\circ} \mathrm{C} / \mathrm{min}$.

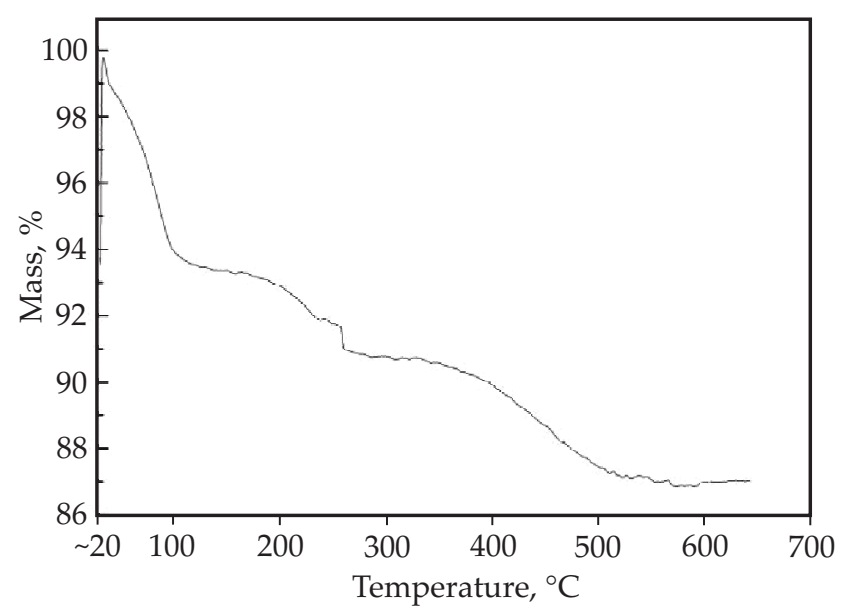

Fig. 5. TGA thermogravimetric analysis of uncoated ATP 


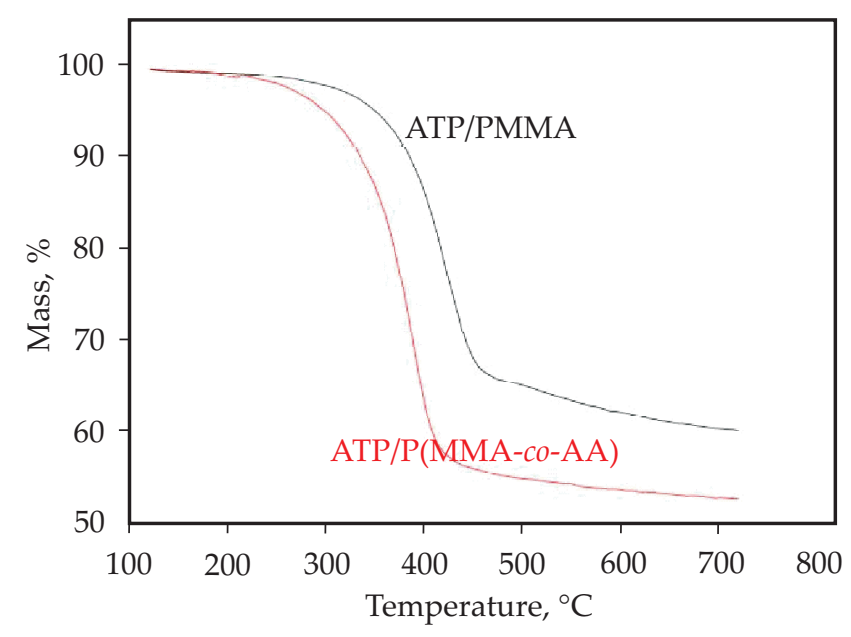

Fig. 6. TGA thermogravimetric analysis of PMMA/ATP, P(MMA-co-AA)/ATP

It can be seen from Fig. 5 that the thermogravimetric analysis process of the attapulgite can be divided into four stages: first, the surface adsorbs water at about $50^{\circ} \mathrm{C}$ and then starts to lose this water: the water loss rate is fast and mass loss obvious. The mass loss is relatively constant between $250^{\circ} \mathrm{C}$, which is due to the beginning of loss of crystal water located at the edge of the channel. The mass loss decreased gently between $300 \sim 500^{\circ} \mathrm{C}$, which may be caused by the heat absorption of this part of the crystal water and structured water; after $500^{\circ} \mathrm{C}$, the curve does not change significantly, the dehydration volume decreases, the dehydration rate decreases, and the quality loss phenomenon does not occur. Obviously, it further shows that the internal hydroxyl structure of attapulgite is damaged and the pore structure collapsed [15].

Figure 6 shows the thermogravimetric curves of PMMA as the shell material and P(MMA-co-AA) as the shell material in order to explore the influence of the addition of acrylic acid on the coating effect of attapulgite, and the two curves represent respectively MMA and MMA-AA, which are used as comonomers. Compared with pure PMMA/ATP, the initial degradation temperature of P(MMA-co-AA)/ATP is reduced by about $23^{\circ} \mathrm{C}$. The pyrolysis process of acrylic shell material has a mass loss of about $1.29 \%$, which is significantly higher than the $0.5 \%$ mass loss of pure PMMA/ATP. Therefore, the addition of acrylic acid can significantly improve the coating efficiency of attapulgite by the shell material, increase the copolymer conversion and polymerization rate, and can greatly reduce the thermal stability of the shell material.

\section{Infrared analysis}

The FT-IR spectra of pure attapulgite samples, acidtreated ATP at $60^{\circ} \mathrm{C}$ and acid-treated ATP at $70^{\circ} \mathrm{C}$ are shown in Fig. 7.

The characteristic absorption band of pure attapulgite at $3498-3653 \mathrm{~cm}^{-1}$ represents the hydroxyl vibration

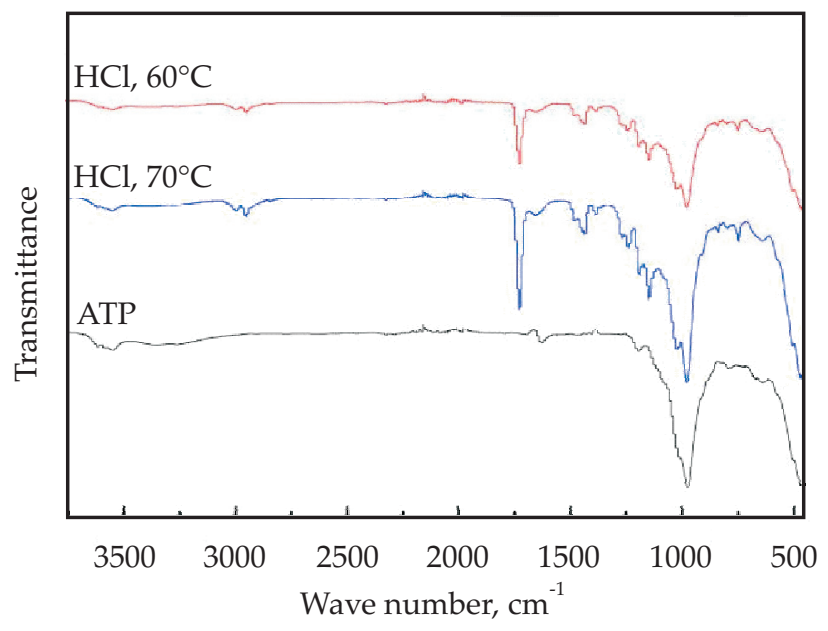

Fig. 7. Infrared test results of uncoated ATP, $60^{\circ} \mathrm{C}$ acidification treatment, $70^{\circ} \mathrm{C}$ acidification treatment

absorption peak of coordinated water in the ATP crystal tunnel. The absorption peak at $1628 \mathrm{~cm}^{-1}$ corresponds to the bending vibration of zeolite water. The absorption at $975 \mathrm{~cm}^{-1}$ should be the bending vibration of the hydroxyl group. In addition, it can be found in the FT-IR that the absorption band around $425 \mathrm{~cm}^{-1}$ is the characteristic absorption peak of the Si-O-Si bending vibration. After acidification and modification of attapulgite with hydrochloric acid, new absorption peaks appeared at $1386-1534 \mathrm{~cm}^{-1}$ and $1724 \mathrm{~cm}^{-1}$, and $1386-1534 \mathrm{~cm}^{-1}$ that originated from methyl hydrocarbons. The characteristic absorption peak of the bond, the absorption peak of the carbonyl group at $1724 \mathrm{~cm}^{-1}$, indicates that PMMA was successfully grafted on the surface of attapulgite. When the second comonomer AA is added there is a $\mathrm{C}=\mathrm{O}$ group stretching vibration peak in the ester group at $1730 \mathrm{~cm}^{-1}$, as shown in Fig. 8, but there is no hydroxyl vibration absorption peak of the coordination water. From the spectrum it can be seen that there are both the chemical structure of acrylic acid and the structure of methyl

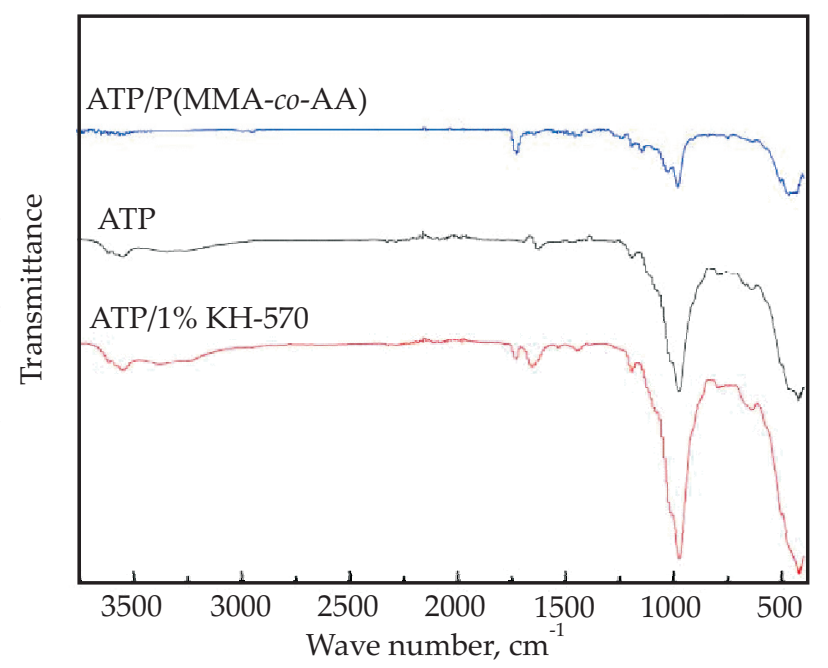

Fig. 8. Infrared test results of uncoated ATP, PMMA/ATP, P(MMA-co-AA)/ATP 
methacrylate, indicating that the P(MMA-co-AA) copolymer coating is basically complete.

\section{CONCLUSIONS}

Acrylic resin was used as a shell material. After attapulgite was modified by the silane coupling agent $\mathrm{KH}-570$, the surface of the attapulgite (ATP) was chemically coated by in situ polymerization to prepare the modified attapulgite shell. The core microcapsule flame retardant, the amount of coupling agent and the composition of the shell material all have a certain influence on the coating effect.

Observation of the surface morphology and thermal performance test analysis show that PMMA forms a single shell material for coating. When the amount of silane coupling agent $\mathrm{KH}-570$ is $1 \%$ of the mass of attapulgite, the coating effect is the best, and heating or acidification of modified attapulgite will reduce the coating effect.

Using P(MMA-co-AA) as the shell material has a better coating effect on attapulgite, and the coating thickness is significantly increased compared with PMMA shell material, which improves the copolymer conversion rate and polymerization rate. At the same time, the addition of AA can greatly reduce the thermal decomposition temperature of the microcapsule shell material, which is beneficial to the flame retardant performance of attapulgite.

\section{REFERENCES}

[1] Wang B., Lei X.: Bulletin of the Chinese Ceramic Society 2015, 3, 738.

[2] Sun H., Su Q., Wang Y. et al.: Chemical Management 2018, 03, 10.

[3] Li X.: "Study on attapulgite modified phosphorus-containing polyacrylate emulsion and its flame retardant properties", Shaanxi University of Science and Technology, 2019.

[4] Gao H.: "Research on modification and application of attapulgite", Anhui University, 2010.

[5] Navarchian A.H., Najafifipoor N., Ahangaran F.: Progress in Organic Coatings 2019, 132, 288. https://doi.org/10.1016/j.porgcoat.2019.03.029

[6] Yue W., Ai L., Jin H., Yifan H.: Chemical Engineering and Equipment 2018, 11, 281.

[7] Wang C., Dai L., Yang Z. et al.: Polymers 2018, 10 (11), 1236.

https://doi.org/10.3390/polym10111236

[8] Wang L., Lv Y., Wang T., Xu M.: Proceedings of the International Conference on Chemical, Material and Food Engineering, Series: Advances in Engineering Research 2015. https://doi.org/10.2991/cmfe-15.2015.52

[9] Ahangaran F., Hayaty M., Navarchian A.H. et al.: Polymer Testing 2017, 64, 330.

https://doi.org/10.1016/j.polymertesting.2017.10.014

[10] Ahangaran F., Hayaty M., Navarchian A.H. et al.: Applied Surface Science 2017, 399, 721. https://doi.org/10.1016/j.apsusc.2016.12.116

[11] Ye Z., Zhang P., Zhang J. et al.: Progress in Organic Coatings 2019, 127, 211. https://doi.org/10.1016/j.porgcoat.2018.11.021

[12] Teeka P., Chaiyasat A., Chaiyasat P.: Energy Procedia 2014, 56, 181. http://dx.doi.org/10.1016/j.egypro.2014.07.147

[13] Wang P., Xu G.: Polymer Materials Science and Engineering 2005, 03, 266.

[14] "A preparation method of attapulgite modified by silane coupling agent: CN200610039834.9 [P]", Jiangnan University, 2006-10-11.

[15] He S., Mo L., Xu J.: China Paper 2014, 33 (10), 10.

Received 11 VIII 2020.

\section{Rapid Communications}

Przypominamy Autorom, że publikujemy artykuły typu Rapid Communications - prace oryginalne wyłącznie w języku angielskim (o objętości 4-5 stron maszynopisu z podwójną interlinią, zawierające 2-3 rysunki lub 1-2 tabele), którym umożliwiamy szybką ścieżkę druku (do 3 miesięcy od chwili ich otrzymania przez Redakcję). Artykuł należy przygotować wg wymagań redakcyjnych zamieszczonych we wskazówkach dla P.T. Autorów.

We remind Authors that we publish articles of the Rapid Communications type - the original papers, in English only (with a volume of 4-5 pages of double-spaced typescript, containing 2-3 figures or 1-2 tables), which allow a fast print path (up to 3 months from when they are received by the Editorial Board). The article should be prepared according to the editorial requirements included in the Guide for Authors. 